\title{
Wind Potential in Argentina, situation and prospects
}

\author{
Author: MSc. Carlos V. M. Labriola \\ Energy and Sustainability Group -Electrotecnia Department - Faculty of Engineering \\ National University of Comahue - Buenos Aires 1400, Neuquén (8300) Argentina. \\ carloslabriola54@yahoo.com.ar - clabriola@uncoma.edu.ar
}

\begin{abstract}
Patagonia Region in Argentina has one of the best wind characteristics of the world. From 1980 there were local motivation, from Governmental Investments to Privates ones. During the 1990s there was an expansion of energy production investments from non renewable energy fuels which stopped in 1999. The energy needs due to demand rise changes from 300MW per year (1999) to 800MW per year (2006). Since 2005 there have been motivation from different private companies including oil ones, to produce electricity from wind energy. This work describes the wind potential in Patagonia in three aspects: meteorological wind potential, technological one based on technical availabilities in Argentina, and business potential for wind energy investments. Also this work intends to show an approach for the present and actual figures on these upper aspects.
\end{abstract}

\section{Key words:}

Patagonia, Wind Energy, Wind Potential, Manufacturing, Business, Technology

\section{Introduction:}

Argentina has one of the best regions of wind characteristics, it is The Patagonia. Its name comes from the marks that the Indian's feet made on soil when Magallanes saw them during one stop of his travel around the world. The meteorological average wind speed in this region is from 5 to $10 \mathrm{~m} / \mathrm{s}$ approximately at $10 \mathrm{~m}$ height [1], which is represented in the first Wind Map of Patagonia by Dr. Barros. The meteorological wind power at $10 \mathrm{~m}$ height of Patagonia is about 200.000MW [1].

Wind behaviour is quit special in Patagonia: low average wind speed correspond to places where wind is very seasonal (spring and summer), as Comahue Region (Neuquén - Rio Negro ), but with strong gusts of wind from 30 to $47 \mathrm{~m} / \mathrm{s}$. Also wind direction changes during the gust in $70 \%$ of times during gales [2]. This behaviour is worst near Los Andes Mountain Range.

In 1980 's there were some National State installation and development of wind turbines, but low maintenance and non prevision of teetering condition respectively motivate to abandon these investments. During 1990's Cooperatives of electrical facilities made the first private investment in wind energy to produce electricity for the National Grid [3]. Actually the Cooperative of Comodoro Rivadavia has the biggest wind farm in Argentina (see Table 1).

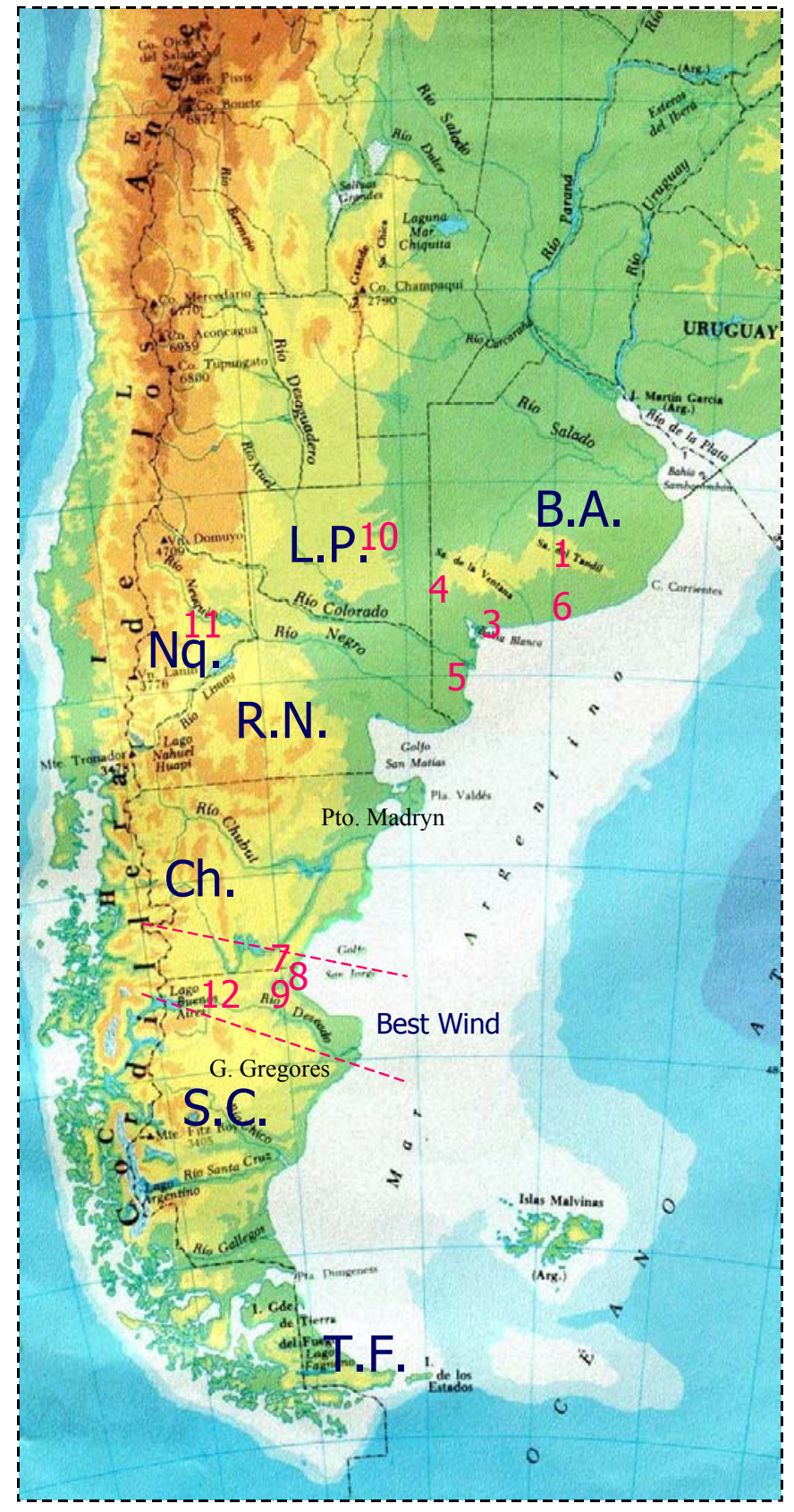

Fig. 1: Patagonia location in Argentina (See Table 1)

During the 1990's, Neuquén, Chubut and Santa Cruz provincial governments offered economical advantages to install a production plant of wind turbines to different companies. Also they have provincial laws including subsidies for wind energy which is plus to National subsidy from National Renewable Energy Law [4]. 
There is small wind turbine production in Córdoba and Buenos Aires (INVAP), which devices would not resist Patagonian gusts of wind.

The National Grid in the Middle and South Patagonia has about $132 \mathrm{kV}$ lines which become saturated during the peak hour. This regional grid needs to be interconnected with the National Grid of $500 \mathrm{kV}$ which will permit to export to the rest of the country from 1000MW (2006: one simple line) to $3000 \mathrm{MW}$ (In the future: two compensated line). The first span of $500 \mathrm{kV}$ from Choele Choel to Puerto Madryn was finished during 2005, but primarily this line will be used to transport energy from Combined Cycle Power Station using residual natural gas
[5]. It is proposed to combine the production of electrical energy with a Wind Farm of 200MW [6].

There are some implementations of Hydrogen obtained by electrolysis of water with energy from wind turbines in Pico Truncado but it is a subsided investment by the National Government. The $\mathrm{H}_{2}$-production is about $1 \mathrm{~m}^{3}$ per day only for R\&D.

The Installed power of Wind Turbines in operation in Argentina is represented in Table 1. The company locations are represented by numbers in Figure 1.

TABLE 1: Wind Turbine Installations in operation in Argentina.

\begin{tabular}{|c|c|c|c|c|c|}
\hline Province & Company (see Fig. 1) & $\begin{array}{l}\text { Wind } \\
\text { Speed }\end{array}$ & Date & Purchaser & $\begin{array}{c}\text { Total } \\
\text { Power } \\
\text { KW }\end{array}$ \\
\hline Buenos & 1.CRETAL - Tandil & $7,2 \mathrm{~m} / \mathrm{s}$ & $26 / 05 / 95$ & MICON $2 \times 400 K W$ & 800 \\
\hline \multirow{5}{*}{ Aires } & 2.CEPA - Pehuen Có & $7,3 \mathrm{~m} / \mathrm{s}$ & $17 / 02 / 95$ & MICON $1 \times 400 K W$ & 400 \\
\hline & 3.CEPA - Bajo Hondo & $7,8 \mathrm{~m} / \mathrm{s}$ & $10 / 12 / 98$ & BONUS $3 \times 600 \mathrm{KW}$ & 1.800 \\
\hline & 4.CED - Darregueira & $7,3 \mathrm{~m} / \mathrm{s}$ & $12 / 10 / 97$ & MICON $1 \times 750 K W$ & 750 \\
\hline & 5.CEMB - M.Buratovich & $7,4 \mathrm{~m} / \mathrm{s}$ & $22 / 10 / 97$ & BONUS $2 \times 600 \mathrm{KW}$ & 1.200 \\
\hline & 6.CEC - Claromecó & $7,3 \mathrm{~m} / \mathrm{s}$ & $26 / 12 / 98$ & $\begin{array}{cr}\text { MICON } & 1 \times 750 \mathrm{KW} \\
& \text { TOTAL }\end{array}$ & $\begin{array}{r}750 \\
5.700\end{array}$ \\
\hline \multirow[t]{5}{*}{ Chubut } & 7.PECORSA & 11,2 & $19 / 01 / 94$ & MICON $2 \times 250 K W$ & 500 \\
\hline & 8.C.Rivadavia & $\mathrm{m} / \mathrm{s}$ & $12 / 09 / 97$ & MICON $8 \times 750 K W$ & 6.000 \\
\hline & 8.CEECR- C.Rivadavia & & $10-12 / 01$ & GAMESA16x660 KW & 10.560 \\
\hline & & & $18 / 3 / 96$ & MICON $1 \times 400 K W$ & 400 \\
\hline & 9.COAGUA- Rada Tili & $10,8 \mathrm{~m} / \mathrm{s}$ & & TOTAL & 17.460 \\
\hline \multirow[t]{2}{*}{ La Pampa } & 10.CSPGA - Gral. Acha & $7,21 \mathrm{~m} / \mathrm{s}$ & $12 / 02$ & NEG-MICON & \\
\hline & & & $02 / 04$ & $\begin{array}{l}1 \times 900 K W \\
\text { NEG-MICON } \\
1 \times 900 K W\end{array}$ & 1.800 \\
\hline Neuquén & 11.COPELCO - Cutral Có & $7,2 \mathrm{~m} / \mathrm{s}$ & $20 / 10 / 94$ & MICON 1x400KW & 400 \\
\hline \multirow[t]{2}{*}{ Santa Cruz } & 12. MPT - Pico Truncado & $9 \mathrm{~m} / \mathrm{s}$ & $\begin{array}{l}02 / 01- \\
02 / 05\end{array}$ & $\begin{array}{l}\text { ENERCON } \\
4 \times 600 \mathrm{KW}\end{array}$ & 2.400 \\
\hline & \multicolumn{4}{|c|}{ TOTAL WIND POWER IN OPERATION, ARGENTINA } & 27.760 \\
\hline
\end{tabular}

Enercon installed a plant for assembling and manufacturing in Brazil for their biggest wind turbines. During July 2006, the first Argentinean private prototype of $1 \mathrm{MW}$ turbine fell down in Comodoro Rivadavia. It belongs to Pescarmona Company.

Dr. Kirchner, Argentinean president, created the new State Energy Enterprise (ENARSA) which will try to develop new non renewable fuel prospecting and renewable energy investments.

The installation of wind turbines is limited to 1,5-2 MW in Argentina, because there are no cranes for more than $50 \mathrm{~m}$ high nacelles. Investments for more than $2 \mathrm{MW}$ per machine, justify to import the respectively crane for $70 \mathrm{~m}$ height.

On the other hand there are some Universities in Argentina that offer research, training and careers related to Renewable Energy. The University of Salta offers an MSc Course mainly oriented to Solar Energy.
National University of Comahue (UNCo) included Renewable Energy in Secondary or High School Teacher Training.

There is a Research Group in Energy and Sustainability (UNCo) which developed a Vertical Axis Wind Turbine particularly for wind characteristics near the mountain range. National University of Austral Patagonia (UNPa) offers a Mechanical Engineer career with specialization in Renewable Energy [7]. National Technological University (UTN) by means of Academic Unit of Confluence, Plaza Huincul, Neuquén, offers a Technical Degree of two years preparing technician for operation and installation of Renewable Energy investments [8].

Specialized Workers salary is from U\$S 500 to U\$S 700 and for ordinary workers U\$S 300 to U\$S 500. 


\section{Prospects into the future:}

The first aspect is to analyze the Meteorological Wind

Potential. Taking into account, Dr. Barros' studies, the wind potential at $10 \mathrm{~m}$ height is about $200.000 \mathrm{MW}$.
If we analyze at different height than $10 \mathrm{~m}$ this potential results in the values shown in Table 2 .

TABLE 2: Wind Potential at different Heights using the log law of wind profile applied to power production

\begin{tabular}{|l|c|c|c|c|c|c|c|}
\hline Magnitude & Power PZr & Zr & Zo & Z & In1 : In (Z/Zo) & In2: In(Zr/Zo) & Pzr.(In1/In2)3 \\
\hline \multirow{4}{*}{ Value } & 200000 & 10 & 0,1 & 34 & 5,83 & 4,61 & 405567 \\
\cline { 2 - 8 } & & & & 50 & 6,21 & 4,61 & 491512 \\
\cline { 2 - 8 } & & & & 60 & 6,40 & 4,61 & 536053 \\
\cline { 2 - 8 } & & & & 78 & 6,66 & 4,61 & 604752 \\
\cline { 2 - 8 } & & & & 100 & 6,91 & 4,61 & 675000 \\
\hline Unit & MW & & & 140 & 7,24 & 4,61 & 778519 \\
\hline
\end{tabular}

Z: heights obtained from the performance of VESTAS and ENERCON turbines from 400kW to 3MW.

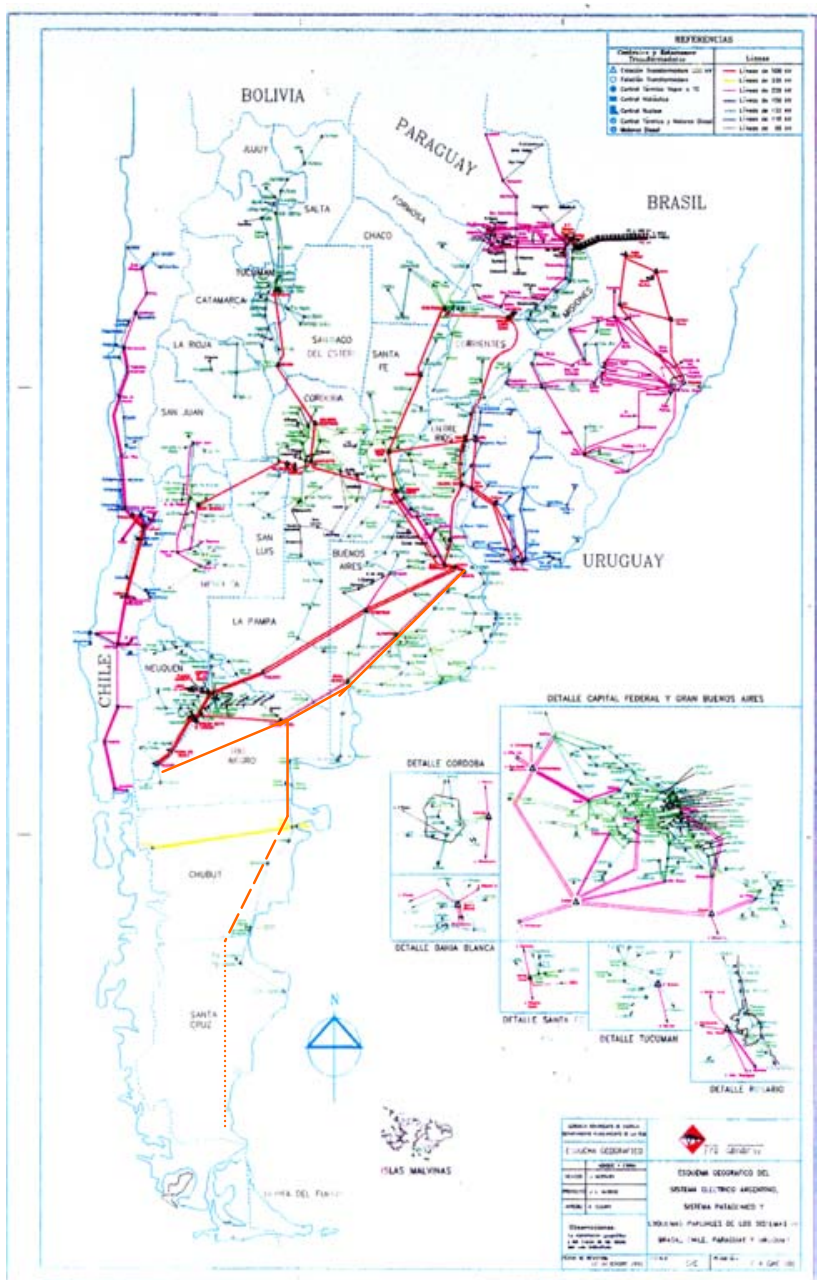

Map References:

$500 \mathrm{kV}$ High Voltage Lines in present operation 500kV High Voltage Lines in operation on 2007 $500 \mathrm{kV}$ High Voltage Lines in future operation

Fig. 2: High Voltage System in Argentina

The second aspect is the Technological Wind Potential. Some considerations are necessary to estimate this aspect:
1. There is a constraint about height of cranes used to fit the nacelles. The availability of cranes is up to $50 \mathrm{~m}$ height.

2. In this way the power is limited between 1 and $2 \mathrm{MW}$ in the best condition of wind characteristic.

3. It is necessary a High Voltage Transmission System of $500 \mathrm{kV}$ to export energy to others areas or countries.

Taking into account the upper considerations on Atlantic area of Patagonia from Golfo San Matías to Río Gallegos, a wind power generation of about $20.000 \mathrm{MW}$ using machines around 1,5 could be obtained in Patagonia in the best case at present [8][9].

The available Total Power from electrical generation plants connected to the Whole Sale Energy Market in Argentina is about $24000 \mathrm{MW}$. As electrical procedures establish, $20 \%$ of installed available power stations can be supplied by wind energy, so the possible local wind energy market today is up to $4800 \mathrm{MW}$.

The last limitation in Argentina for wind energy is the distribution transmission line system of $132 \mathrm{kV}$. The present local High Voltage System has $132 \mathrm{kV}$ lines which are saturated. The new $500 \mathrm{kV}$ line from Choele Choel to Puerto Madryn was finished during 2005 [10]. It can transmit 1000MW. During 2006, a local company offered to install a power plant from 350 to 500MW with natural gas as fuel and a wind farm up to $200 \mathrm{MW}$ near Puerto Madryn. The second track of $500 \mathrm{kV}$ line will be installed from Puerto Madryn to Pico Truncado. This city has a County's Investment of 2,4MW of wind energy (see Table 1) and has an experimental plant for producing Hydrogen. This line will be finished during 2007, (expected for August). The third track of $500 \mathrm{kV}$ line from Pico Truncado to Río Gallegos is projected to be in service in the next future (2010). This Patagonian $500 \mathrm{kV}$ System was primarily designed to export non renewable energy, although there is capability to export $1000 \mathrm{MW}$ from renewable or non renewable energy.

In the case to intend installations of Manufacture Wind Turbine Company, there are some different strategic sites. Table 3 presents a comparison of North and middle location in Patagonia. 
TABLE 3: Comparison of locations to install a manufacturing Wind Turbine Plants

\begin{tabular}{|l|l|l|l|}
\hline \multicolumn{1}{|c|}{ Place } & \multicolumn{1}{c|}{ Advantages } & \multicolumn{1}{c|}{ Disadvantages } & \multicolumn{1}{c|}{ Other Considerations } \\
\hline $\begin{array}{l}\text { Neuquén- } \\
\text { Cipolletti }\end{array}$ & $\begin{array}{l}\text { It is in the midway between Atlantic } \\
\text { and Pacific Oceans with access to } \\
\text { respective harbors for export. Routes } \\
\text { and train is available to access the } \\
\text { harbors. }\end{array}$ & $\begin{array}{l}\text { It is not near the best places } \\
\text { of wind in Patagonia. }\end{array}$ & $\begin{array}{l}\text { It is in the Comahue } \\
\text { region. North Patagonia. } \\
\text { Harbor in Argentina: San } \\
\text { Antonio Este. } \\
\text { Harbor in Chile: Saavedra } \\
\text { through Temuco. }\end{array}$ \\
\hline $\begin{array}{l}\text { Puerto } \\
\text { Madryn - } \\
\text { Comodoro } \\
\text { Rivadavia }\end{array}$ & $\begin{array}{l}\text { It is near the best places of wind in } \\
\text { Patagonia. They are near the harbor for } \\
\text { Atlantic Ocean }\end{array}$ & $\begin{array}{l}\text { There is no a good harbor in } \\
\text { Chile for exporting wind } \\
\text { turbines through Pacific } \\
\text { Ocean at this latitude. }\end{array}$ & $\begin{array}{l}\text { It in the middle of } \\
\text { Atlantic area. }\end{array}$ \\
\hline
\end{tabular}

The third aspect is to consider the Business Potential to develop wind energy investments.

The worker salaries are around Asian figures, and therefore the worker market is competitive. Then the installation costs can be cheaper than in Europe or Asia with good technical level because of the energy installations during the 1990s.

The Wholesale Electrical Energy Market price in Argentina is the cheapest in Latin America, from 2001. In 2000 the average energy price was about 0,004 $\mathrm{U} \$ \mathrm{~S} / \mathrm{kW}$ and now is about $0,001 \mathrm{U} \$ \mathrm{~S} / \mathrm{kW}$ and fixed by de Secretary of Energy Office[10]. During 2006, the Government establish free prices for new private energy contracts and deals between Energy Generation Companies and Demand Companies. In this way there was a partial free-trade in Whole Sale Energy Market.

It is possible to analyze different situations for investments taking into account different energy prices with the following consideration frame:

- Energy prices in the Whole Sale Energy Market: present value $(1,3 \mathrm{U} \$ \mathrm{~S} / \mathrm{MW})$ and possible ones in the future (2,3 to $4 \mathrm{USS} / \mathrm{MW})$.

- Period of useful operation: 25 years. It is the ordinary period for generation engines

- Investment: Wind Farm of $100 \mathrm{MW}$ at 1000U\$S/MW: Total of U\$S 100.000.000.

- Costs of Maintenance/Operation U\$S100.000 per year - It is supposed three workers for maintenance and two form operations.
- Cost of Land: it is negligible because they are fiscal or public lands.

- Coefficient Plant: Patagonia is divided in two regions: $\mathrm{CP}=0,3$ in North Patagonia and $\mathrm{CP}=0,4$ in Atlantic and Middle land zone of Chubut and Santa Cruz.

Taking into account the upper considerations on Net Present Value (NPV) calculations, their results are in Table 4.

TABLE 4: Economical Approach for Wind Energy Investment

\begin{tabular}{|c|c|c|}
\hline Comparison & $\begin{array}{c}\text { Plant Coeff. : } \\
0,30\end{array}$ & $\begin{array}{c}\text { Plant Coeff. : } \\
0,40\end{array}$ \\
\hline Energy Price & $\begin{array}{c}\text { Net Present } \\
\text { Value }\end{array}$ & $\begin{array}{c}\text { Net Present } \\
\text { Value }\end{array}$ \\
\hline 1,3 & Negative & Negative \\
\hline 2,3 & Negative & Positive \\
\hline 4 & Positive & Positive \\
\hline (U\$S/MW) & & \\
\hline
\end{tabular}

NPV was chosen because it is the investing indicator more simple and effective than others. Also this economical comparison tries to be only and approach to good conditions for wind energy business.

\section{Conclusion and Considerations:}

It is possible to produce wind energy in Argentina but the following considerations in Table 4 should be put in practice:

TABLE 4: Conclusions and Considerations

\begin{tabular}{|l|l|}
\hline \multicolumn{1}{|c|}{ Consideration } & Reference \\
\hline $\begin{array}{l}\text { With the actual technology the Meteorological Wind Potential is between 500.000 to 600.000 MW, with the } \\
\text { limitation of cranes availability in Argentina. }\end{array}$ & Table 2 \\
\hline $\begin{array}{l}\text { The best area to produce wind energy in Argentina is in Chubut and Santa Cruz provinces (Puerto Madryn - } \\
\text { Comodoro Rivadavia - Pico Truncado - Gobernador Gregores). }\end{array}$ & 1985 \\
\hline $\begin{array}{l}\text { There are High Voltage Transmission Lines (500kV) to Puerto Madryn, in the next future (august 2007) there } \\
\text { will be to Pico Truncado. It is possible to transmit up to 500MW today of Wind power in Argentina from } \\
\text { Patagonia. }\end{array}$ & $\begin{array}{l}\text { 2006 } \\
\end{array}$ \\
\hline
\end{tabular}




\begin{tabular}{|c|c|}
\hline $\begin{array}{l}\text { The target in the next future (2020) is to obtain } 8 \% \text { from renewable Energy in the Whole sale Energy Market } \\
\text { (Today } 8 \% \text { represents nearby } 1600 \mathrm{MW} \text { ). Also with the limit of } 20 \% \text {, it could be possible to generate up to } \\
4800 \mathrm{MW} \text { but more } 500 \mathrm{kV} \text { HVTL are necessary to export the energy to other areas or countries. }\end{array}$ & $\begin{array}{l}\text { [4] National } \\
\text { Law, } 2006\end{array}$ \\
\hline $\begin{array}{l}\text { The present fixed energy price in the Whole Sale Market by Argentinean Secretary of Energy is not enough } \\
\text { for wind energy investment. It is necessary to rise the energy price to between } 2 \text { to } 3 \mathrm{US} / \mathrm{MW} \text { for } \mathrm{CP}=0,4 \text { or } \\
\text { nearby } 4 \mathrm{U} \$ \mathrm{~S} / \mathrm{MW} \text { for } \mathrm{CP}=0,3 \text {, by means of new energy contracts or/and National plus Provincial subsidies. } \\
\text { These figures permits to begin thinking about wind energy generation business could be profitable. } \\
\text { It is necessary to convert the subsidies from } \$ \text { to dollar with the same figure. }\end{array}$ & $\begin{array}{l}\text { Table } 4 \\
\text { [8] Labriola, } \\
2006 . \\
\text { [4] National } \\
\text { Law, } 2006\end{array}$ \\
\hline $\begin{array}{l}500 \mathrm{kV} \text { Transmission Lines on Neuquén are very close to Transmission Line System of South Chile. It is } \\
\text { possible to interconnect them for exporting energy at international prices instead of natural gas. But it is not } \\
\text { possible in the present condition of energy deficit in Argentina. }\end{array}$ & $\begin{array}{l}\text { [8] Labriola, } \\
2006 .\end{array}$ \\
\hline $\begin{array}{l}\text { If it is not possible to increase the present price or subsidies, it is necessary } 50 \% \text { of capital participation by } \\
\text { the Argentinean Government. }\end{array}$ & $\begin{array}{l}\text { [8] Labriola, } \\
2006\end{array}$ \\
\hline $\begin{array}{l}\text { Local careers and technician training are already available. These qualified workers can be included into } \\
\text { Wind Energy production in construction, installation, operation and supervision areas. Salaries are one third } \\
\text { to one half of international ones for qualified workers. }\end{array}$ & $\begin{array}{l}\text { [7] Labriola, } \\
2005 \\
\text { [8]Labriola, } \\
2006\end{array}$ \\
\hline
\end{tabular}

The technical scene and an approach to economical scene is set. As we all know any engineering system is embedded in political, juridical, economical and social systems on which it depends. This is to say that technical decisions and performance is conditioned by many and different factors beyond engineering issues, mainly in developing countries.

Finally we must view the development of energy systems in general and wind energy in particular, as holistic and multidisciplinary processes which lead to decision making [11]

\section{Acknowledgements:}

- To UNCo which permits my specialization.

- To UTN which permits to apply on working areas.

- To National University of La Plata which permits to continue my PhD studies.

\section{References:}

[1] Barros, V.: Wind Map of Argentina with 20 years of Data, 1985.

[2] Lässig, E. -Palese, C.: Study of wind behaviour in Comahue Region, International Congress of Electrical Distribution, Mar del Plata, Buenos Aires Province, 1990.

[3] COPELCO: First International Course o Wind Energy Maintenance in Latin America, Cutral Có, Neuquén, organized by COPELCO Cooperative, MICON and CREE, March 1995.

[4] National Law of Renewable Energy, 2006: It include geothermal and Biomass in the former RE Law (1998) which proposed Wind and Solar energy subsidies with \$1/MW of RE generation.

[5] N.E.E.P: National Electrical Energy Plan, 1990-2000.

[6] Trelew, 2006: Provincial announcement that there will be a local Investment of nearby 500-700MW of Renewable and Non Renewable Energy Power plants at $50 \mathrm{Km}$ form Trelew, Chubut province.

[7] Labriola, C., 2005: Technicature of Renewable Energy and Environment, National Technological University, Argentina 2003-2005.

[8] Labriola, C., 2006: Presentation during the annual meeting of "European Renewable Energy RTD and International Cooperation", Florence, Italy august 2006.

[9] Labriola, C., 2000: $5^{\text {th }}$. Chapter of Thesis of MSc. Course in The University of Reading, United Kingdom, September, 2000.

[10] CAMMESA, 2006: Whole Market Electrical Company of Energy Transactions, Reports from 1999-2006.

[11] Blockley, D. -Godfrey, P.,: "Doing it differently", Thomas Telford Limited, Bristol, UK, 2000. 